\title{
Taking Advantage of Taguchi Design Method to Optimize Medium Culture Conditions for Producing Recombinant Follicle Stimulating Hormone
}

\section{Minoo Qafary ${ }^{1 *}$, Mohsen Gharanfoli ${ }^{1}$ and Seyed Mehdi Qafari²}

${ }^{1}$ Department of Genetics at Reproductive Biomedicine Research Centre, Royan Institute for Reproductive Biomedicine, Tehran, Iran

${ }^{2}$ Systems Biotechnology Department, Institute of Industrial and Environmental Biotechnology, National Institute of Genetic Engineering and Biotechnology (NIGEB), Tehran, Iran

\begin{abstract}
Medium culture optimization is an Effective, available and financially affordable way to improve production of recombinant proteins produced by genetic engineering. The existence of varieties of parameters and different levels for each, makes it complex, time-consuming and expensive to determine the optimum point of all parameters by applying the factorial method. To overcome these difficulties, in this study, Taguchi robust design method was employed. The environmental parameter such as temperature, $\mathrm{pH}$ and glutamine concentration in 4 different levels were considered. According to the design of the experiments, FSH titer was measured. In comparison with the control condition, 14.92 fold overexpression was observed. The best level for these parameters was $\mathrm{pH}=7.0,28^{\circ} \mathrm{C}$ and 2 mM Glutamine concentration
\end{abstract}

Keywords: Taguchi method; Genetic engineering; Statistical experimental design; Glutamine temperature; Optimization

\section{Introduction}

According to a released statistic from the world health organization (WHO), it had been found that $25 \%$ of the couples are affected by infertility in developing countries. For overcoming this challenge, it is essential to provide complex hormones belong to glycoprotein hormones family, using genetic engineering. One of the most important and common glycoproteins in infertility treatment of men and women, which produce with this method is FSH [1-3]. Complex post-translational modifications of this hormone such as disulfide bond and glycolization leave no choice to use mammalian cells as a host. The difficulty of cloning, low recombinant protein titer and the hard purification process of these cell lines, imposes significant costs.In this cause, lots of companies and institutes try to produce the most amount of hormones with the least price $[4,5]$. Environmental parameters such as temperature [6-8], $\mathrm{pH}[6,9,10]$ and glutamine concentration [10-12] have a significant effect on recombinant cells viability and the amount of hormone titer by this cells.

Using the traditional method for determining the optimum level of different parameters, involves the study of one variable at a time, is time-consuming and costly. In this cause to overcome the limitation and difficulty of applying this kind of methods, we used Taguchi Orthogonal array design. Taguchi method is a simple statistical method applying one-way ANOVA for analysis of variance and the tables of orthogonal arrays [13]. Using this approach, we apply a system of arrays which permits estimation of a maximum number of key effects in an orthogonal fashion with a minimum number of experimental runs [14]. This method was applied in different fields of biotechnology such as food and industrial fermentations [15-17], Molecular biology [1820], wastewater treatment and bioremediation $[16,21,22]$ and health care [23-25]. In this work, we explained the application of this method for optimization of medium culture parameters, for producing FSH, a complex glycoprotein hormone, in the recombinant $\mathrm{CHO}-\mathrm{c} 111$ cell line.

\section{Material and Methods}

\section{Taguchi orthogonal design}

To solve our problem, the low expression of FSH hormone in rCHO cells, effective environmental parameters which influence the cell viability and recombinant protein expression opted. Essential environmental parameters which considered for designing the experiment were $\mathrm{pH}$ of medium culture, the temperature of culturing and the amount of glutamine concentration in medium culture. Recombinant cells according to their special features prefer to live in a different level of these parameters. Combination of these parameters affects other levels of parameters preference. For example, if cells growth in $\mathrm{pH}=7.3$ at $2 \mathrm{mM}$ glutamine concentration, these cells may prefer $4 \mathrm{mM}$ glutamine concentration at $\mathrm{pH}=6.8$. In this case, for all parameters, according to their acceptable range for culturing 4 levels were considered.(for temperature $37^{\circ} \mathrm{C}, 34^{\circ} \mathrm{C}, 31^{\circ} \mathrm{C}$ and $28^{\circ} \mathrm{C}$, for $\mathrm{pH}$ 6.7, 7.0, 7.3 and 7.6 and for glutamine concentrations $0 \mathrm{mM} / \mathrm{L}, 2 \mathrm{mM} / \mathrm{L}$, $4 \mathrm{mM} / \mathrm{L}$ and $6 \mathrm{mM} / \mathrm{L}$ ).

Designing the experiment with these parameters and the chosen levels by applying most of the custom statistical methods, such as factorial approach, which considers all possible combination of parameters and their states needs $4^{*} 4^{\star} 4=64$ experiments. Considering at least 3 times repetition at least 192 experiments need to be done. Ignoring the imposes cost of these numbers of experiments, applying them is too much time-consuming and expensive. Using $\mathrm{L}_{16}$ orthogonal limits the numbers of an experiments to 16. (48 times considering the repetition). The parameters and their levels with designed experiment were shown in Table 1 . The levels of chosen parameters are shown by 1 to $4[26,27]$.

Computing the degree of freedom is vital for opting the appropriate orthogonal array. The degree of freedom calculated one less than the number of experiments. At this work, the degree of freedom is 15 .

*Corresponding author: Minoo Qafary, Department of Genetics at Reproductive Biomedicine Research Centre, Royan Institute for Reproductive Biomedicine Tehran, Iran, Tel: +98(21)66409517; +98(21)61113285; Fax: +98(21)66404680; E-mail: mi.qafary@ut.ac.ir

Received July 16, 2018; Accepted August 13, 2018; Published August 17, 2018

Citation: Qafary M, Gharanfoli M, Qafari SM (2018) Taking Advantage of Taguch Design Method to Optimize Medium Culture Conditions for Producing Recombinant Follicle Stimulating Hormone. J Biom Biostat 9: 409. doi: 10.4172/21556180.1000409

Copyright: @ 2018 Qafary M, et al. This is an open-access article distributed under the terms of the Creative Commons Attribution License, which permits unrestricted use, distribution, and reproduction in any medium, provided the original author and source are credited. 
Designing the test, practical steps of the investigation were in progress according to that. The statistical analysis and graphical analysis of the obtained data in this work were done by Minitab software (Pennsylvania University, USA)

\section{Practical steps}

In this study, recombinant Chinese Hamster Ovary C111 cells with p-VITRO expression vector contain $\alpha$ and $\beta$ genes of FSH subunit were applied. Cells were cultured at serum-free and glutamine-free medium (LONZA, Switzerland).For cell process, cells were cultured in the T-75 flask. The equal number of cells were cultured at $37^{\circ} \mathrm{C}$, $5 \% \mathrm{Co} 2$ concentration, $2 \mathrm{mM}$ glutamine concentration, $\mathrm{pH}=7.3$ and 95\% humidity which are the common condition for cell culture. Subsequently, after providing primary condition (cells grown in the identical environmental condition), cells were transformed to the new mediums determined by Taguchi robust design. At least 3 passages were applied for adaptation of the cells to the new conditions. FSH titer was measured by Elisa kit (FAN AZMA, Iran). Each step was repeated at least 3 time for limitation the errors of handling.

\section{Result and Conclusion}

In this study, the experiments designed and analyzed by Minitab software. The designed experiments and the obtained resulst and their analyses are shown in Table 2 . Analyze of the experiments were carried out by $\mathrm{S} / \mathrm{N}$ ratio and ANOVA. According to the obtained results of our study shows that the optimum levels of different parameters have altered on the production of recombinant proteins when they work simultaneously in comparison to working separately. The effect of these parameters and their best level when work simultaneously altered.

Where $\mathrm{n}$ is the total number of the experiments in the array and $\mathrm{Yi}$ is the mean percentage of FSH titer for the ith experiment, $\mathrm{S} / \mathrm{N}$ rate calculated by this formula.

$$
S N_{L}=-10 \log \left(\frac{\sum_{i=1}^{n} 1 / y_{i}^{2}}{n}\right)
$$

As it comes from the formula, "the larger the best" strategy were applied in this research. The goal of this study was introducing the condition which in that the most amount of FSH titer obtaines. After calculation of $\mathrm{S} / \mathrm{N}$ ratio for each experiment, the delta for each parameter was determined according to the following formula.

\section{$\mathrm{D}=\operatorname{delta}=\mathrm{S} / \mathrm{Nmax} \_\mathrm{S} / \mathrm{Nmin}$}

The variation of delta showed the importance and effectiveness of each parameter in the maximization of FSH titer. As it is shown in Table 3, the greatest variation belongs to temperature. Decreasing the temperature to $28^{\circ} \mathrm{C}$ is around 16 times more effective than altering

\begin{tabular}{|c|c|c|c|}
\hline Levels & Temperature $\left({ }^{\circ} \mathrm{C}\right)$ & pH & Glutamine concentration (mM) \\
\hline 1 & 28 & 6.7 & 0 \\
\hline 2 & 31 & 7.0 & 2 \\
\hline 3 & 34 & 7.3 & 4 \\
\hline 4 & 37 & 7.6 & 6 \\
\hline
\end{tabular}

Table 1: Parameters and their levels.

\begin{tabular}{|c|c|c|c|c|c|}
\hline Experiments & Temperature $\left({ }^{\circ} \mathrm{C}\right)$ & L-Glutamine concentration (mM) & $\mathrm{pH}$ & MEAN 1 & SNRA1 \\
\hline 1 & 1 & 1 & 1 & 106.3 & 60.0545 \\
\hline 2 & 1 & 2 & 2 & 1122.8 & 61.0060 \\
\hline 3 & 1 & 3 & 3 & 956.4 & 59.6128 \\
\hline 4 & 1 & 4 & 4 & 901.7 & 59.1012 \\
\hline 5 & 2 & 1 & 2 & 803.8 & 58.1030 \\
\hline 6 & 2 & 2 & 1 & 839.2 & 58.4773 \\
\hline 7 & 2 & 3 & 4 & 705.1 & 56.9650 \\
\hline 8 & 2 & 4 & 3 & 729.6 & 57.2617 \\
\hline 9 & 3 & 1 & 3 & 168.5 & 44.5320 \\
\hline 10 & 3 & 2 & 4 & 181.3 & 45.1680 \\
\hline 11 & 3 & 3 & 1 & 196.8 & 45.8805 \\
\hline 12 & 3 & 4 & 2 & 170.2 & 44.6192 \\
\hline 13 & 4 & 1 & 4 & 50.4 & 34.0486 \\
\hline 14 & 4 & 2 & 3 & 68.7 & 36.7391 \\
\hline 15 & 4 & 3 & 2 & 75.2 & 37.5244 \\
\hline 16 & 4 & 4 & 1 & 55.8 & 34.9327 \\
\hline
\end{tabular}

Table 2: The designed experiments by Taguchi method and the obtained data.

\begin{tabular}{|c|c|c|c|}
\hline Level & Temperature $\left.{ }^{\circ} \mathbf{C}\right)$ & L-Glutamine concentration (mM) & 49.18 \\
\hline 1 & 59.94 & 50.35 \\
\hline 2 & 57.70 & 50.00 \\
\hline 3 & 45.05 & 48.98 \\
\hline 4 & 35.81 & 1.37 & 49.54 \\
\hline Delta & 24.13 & 48.82 \\
\hline Rank & 1 & 3.49 \\
\hline
\end{tabular}

Table 3: Response table for signal to noise ratios. 


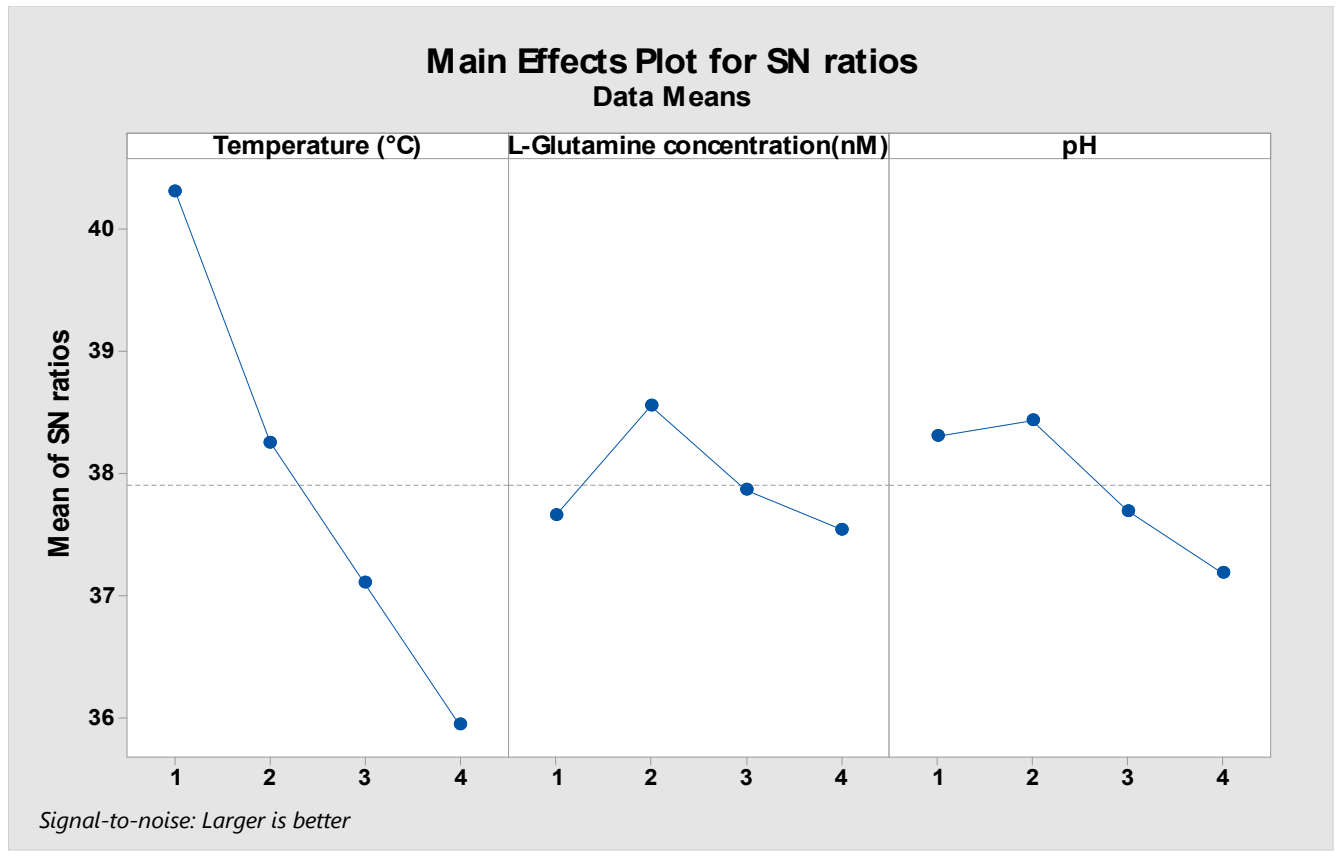

Figure 1: Mean of signal to noise ratios for parameters.

two other parameters. Altering the $\mathrm{pH}$ value of medium culture is more effective than glutamine concentration but it's not considerable in comparison to temperature.

Their best level of each parameter and the order of their importance and effectiveness were determined (Figure 1). The common condition for mammalian cells growth is $37^{\circ} \mathrm{C}$ at $\mathrm{pH}=7.3$ and $2 \mathrm{mM}$ glutamine concentration. As it is shown in Table 2, 14.92 fold overexpression was observed in suggested condition obtained by Taguchi method. Future more, Interestingly the optimum level of temperature, $\mathrm{pH}$ and glutamine were $28^{\circ} \mathrm{C}, 7.3$ and $4 \mathrm{mM}$ when the parameter examined separately(Data not shown), But in our experiment, while exam all parameters simultaneously it changed to $28^{\circ} \mathrm{C}, 7.0$ and $2 \mathrm{mM}$. It means when the effect of parameters investigates simultaneously their effect changes. The interplay of these parameters changes their result and influence. The most effective parameter is temperature and there is no such difference between the effectiveness of $\mathrm{pH}$ and glutamine concentration on the expression of $\mathrm{rCHO}$ (Table 2). As shown in Table 2, when the optimum level of each parameter which is obtained from separate tests applied simultaneously $\left(28^{\circ} \mathrm{C}, 7.3\right.$ and $\left.4 \mathrm{mM}\right)$ on the cell culturing, the expression rate decrease $15 \%$ in comparison with the optimum condition obtained using the Taguchi method $\left(28^{\circ} \mathrm{C}, 7.0,2 \mathrm{mM}\right)$. In comparison with other studies, the effect of the different parameter in variety levels was examined by applying Taguchi methods. Using that we demonstrated the best condition for producing $\mathrm{rFSH}$. This amount of production is considerably more than another experiment. With no more cost, the production of this important medicine in reproductive considerably increased.

\section{References}

1. Nieschlag E, Kamischke A (2010) Empirical therapies for idiopathic male infertility. In: Andrology, Springer, Berlin, Heidelberg, pp: 457-467.

2. Popovic-Todorovic B, Loft A, Lindhard A, Bangsbøll S, Andersson AM, et al. (2003) A prospective study of predictive factors of ovarian response in 'standard' IVF/ICSI patients treated with recombinant FSH. A suggestion for a recombinant FSH dosage normogram. Human reproduction 18: 781-787.
3. Wikland M, Bergh C, Borg K, Hillensjö T, Howles CM, et al. (2001) A prospective, randomized comparison of two starting doses of recombinant $\mathrm{FSH}$ in combination with cetrorelix in women undergoing ovarian stimulation for IVF/ ICSI. Hum Reprod 16: 1676-1681.

4. Olijve W, de Boer W, Mulders JW, van Wezenbeek PM (1996) Recombinat hormones: Molecular biology and biochemistry of human recombinant follicle stimulating hormone (Puregon®). MHR: Basic Sci Reprod Med 2: 371-382.

5. Wurm FM (2004) Production of recombinant protein therapeutics in cultivated mammalian cells. Nat Biotechnol 22: 1393.

6. Hwang SJ, Yoon SK, Koh GY, Lee GM (2011) Effects of culture temperature and $\mathrm{pH}$ on flag-tagged COMP angiopoietin-1 (FCA1) production from recombinant CHO cells: FCA1 aggregation. Appl Microbiol Biotechnol 91: 305-315.

7. Kaufmann H, Mazur X, Fussenegger M, Bailey JE (1999) Influence of low temperature on productivity, proteome and protein phosphorylation of $\mathrm{CHO}$ cells. Biotechnol Bioeng 63: 573-582.

8. Reuveny S, Kim YJ, Kemp CW, Shiloach J (1993) Effect of temperature and oxygen on cell growth and recombinant protein production in insect cell cultures. Appl Microbiol Biotechnol 38: 619-623.

9. Borys MC, Linzer DI, Papoutsakis ET (1993) Culture pH affects expression rates and glycosylation of recombinant mouse placental lactogen proteins by Chinese hamster ovary $(\mathrm{CHO})$ cells. Nat Biotechnol 11: 720.

10. Borys MC, Linzer DI, Papoutsakis ET (1994) Ammonia affects the glycosylation patterns of recombinant mouse placental lactogen-I by chinese hamster ovary cells in a pH-dependent manner. Biotechnol Bioeng 43: 505-514.

11. Hong JK, Cho SM, Yoon SK (2010) Substitution of glutamine by glutamate enhances production and galactosylation of recombinant $\operatorname{lgG}$ in Chinese hamster ovary cells. Appl Microbiol Biotechnol 88: 869-876.

12. Lao MS, Toth D (1997) Effects of ammonium and lactate on growth and metabolism of a recombinant Chinese hamster ovary cell culture. Biotechnol Prog 13: 688-691.

13. Taguchi G, Yokoyama Y (1993) Taguchi methods: design of experiments (Vol. 4). Amer Supplier Inst.

14. Fraley S, Oom M, Terrien B, Date JZ (2006) Design of experiments via Taguch methods: orthogonal arrays. The Michigan chemical process dynamic and controls open text book, USA 2: 4.

15. Prakasham RS, Rao CS, Rao RS, Sarma PN (2005) Alkaline Protease 
Citation: Qafary M, Gharanfoli M, Qafari SM (2018) Taking Advantage of Taguchi Design Method to Optimize Medium Culture Conditions for Producing Recombinant Follicle Stimulating Hormone. J Biom Biostat 9: 409. doi: 10.4172/2155-6180.1000409

Production by an Isolated Bacilluscirculans under Solid-State Fermentation Using Agroindustrial Waste: Process Parameters Optimization. Biotechnol Prog 21: 1380-1388

16. Venkata Mohan S, Chandrasekhara Rao N, Krishna Prasad K, Murali Krishna P, Sreenivas Rao R, et al. (2005) Anaerobic treatment of complex chemical wastewater in a sequencing batch biofilm reactor: Process optimization and evaluation of factor interactions using the Taguchi dynamic DOE methodology. Biotechnol Bioeng 90: 732-745.

17. Zarei M, Aminzadeh S, Zolgharnein H, Safahieh A, Ghoroghi A, et al. (2010) Serratia marcescens B4A chitinase product optimization using Taguchi approach. Iran J Biotechnol 8: 252-262.

18. Cobb BD, Clarkson JM (1994) A simple procedure for optimising the polymerase chain reaction (PCR) using modified Taguchi methods. Nucleic Acids Res 22: 3801-3805.

19. Jeney C, Dobay O, Lengyel A, Ádám É, Nász I (1999) Taguchi optimisation of ELISA procedures. J Immunol Meth 223: 137-146.

20. Rao RS, Kumar CG, Prakasham RS, Hobbs PJ (2008) The Taguch methodology as a statistical tool for biotechnological applications: a critical appraisal. Biotechnol J: Healthcare Nutr Technol 3: 510-523.

21. Daneshvar N, Khataee AR, Rasoulifard MH, Pourhassan M (2007)
Biodegradation of dye solution containing Malachite Green: Optimization of effective parameters using Taguchi method. J Hazard Mater 143: 214-219.

22. Mousavi SM, Yaghmaei S, Jafari A, Vossoughi M, Ghobadi Z (2007) Optimization of ferrous biooxidation rate in a packed bed bioreactor using Taguchi approach. Chem Eng Process: Process Intensification 46: 935-940.

23. Kallel H, Zaïri H, Rourou S, Essafi M, Barbouche R, et al. (2002) Use of Taguchi's methods as a basis to optimize hybridoma cell line growth and antibody production in a spinner flask. Cytotechnology 39: 9-14.

24. Taner T, Antony J (2000) The assessment of quality in medical diagnostic tests: a comparison of ROC/Youden and Taguchi methods. Int J Health Care Qual Assur 13: 300-307.

25. Trabelsi K, Rourou S, Loukil H, Majoul S, Kallel H (2006) Optimization of virus yield as a strategy to improve rabies vaccine production by Vero cells in a bioreactor. J Biotechnol 121: 261-271.

26. Rao RS, Prakasham RS, Prasad KK, Rajesham SSPN, Sarma PN, et al (2004) Xylitol production by Candida sp.: parameter optimization using Taguchi approach. Process Biochem 39: 951-956.

27. Rao RS, Rasheed MA, Kalpana G, Patil DJ, Kumar B (2005) Effect of hydrocarbons and other parameters on hydrocarbon-utilizing Pichia angusta MTCC-225. Appl Biochem Biotechnol 126: 205-214. 